\title{
Natural Regeneration of Indigenous Species under Plantation Forests of Mahoganis (Swietenia macrophylla and Swietenia xaubrevilleana): The Case of Martinique
}

\author{
Philippe Joseph*, Kévine Baillard, Jean-Philippe Claude, Yelji Abati, Séverine Ely-Marius, \\ Stéphane Sophie, Yanis Jean-Francois, Jean-Emile Simphor, Peguy Major \\ UMR EPACE DEV-BIORECA (Biogeography, Ecology, Botany and Ecophysiology), University of the Antilles, Ducos, France \\ Email: *joseph.phil@wanadoo.fr
}

How to cite this paper: Joseph, P., Baillard, K., Claude, J.-P., Abati, Y., Ely-Marius, S., Sophie, S., Jean-Francois, Y., Simphor, J.-E. and Major, P. (2022) Natural Regeneration of Indigenous Species under Plantation Forests of Mahoganis (Swietenia macrophylla and Swietenia xaubrevilleana): The Case of Martinique. Open Access Library Journal, 9: e8306.

https://doi.org/10.4236/oalib.1108306

Received: December 17, 2021

Accepted: January 10, 2022

Published: January 13, 2022

Copyright $\odot 2022$ by author(s) and Open Access Library Inc.

This work is licensed under the Creative Commons Attribution International License (CC BY 4.0).

http://creativecommons.org/licenses/by/4.0/

(c) (i) Open Access

\begin{abstract}
In many geographic areas influenced by tropical and temperate climates, natural forest ecosystems have been destroyed in favour of plantations of allochthonous trees which are economically profitable for different aspects of the timber industry. Some of these mature plantations degrade the soils and inhibit natural regeneration of the local flora; others, due to the physical constraints they impose, can contribute to the installation and the development of autochthonous taxa. The plantations of Swietenia macrophylla and Swietenia xaubrevilleana (Mahoganys) in the Lesser Antilles are part of these processes. To study the natural regeneration process of forest plant species native to Martinique under plantations of Mahoganys, we carried out surveys in thirteen transects (stations) under humid and subhumid bioclimates. The results showed that groups of indigenous species typical of various stages of plant succession colonise the plots of mature Mahoganys. This study suggests that mature plantations of not very competitive introduced forest species may favor the succession of plant communities. It would be therefore possible to use these introduced species (Swietenia macrophylla and Swietenia xaubrevilleana) in reforestation programs of Lesser Antilles biotopes with sylvicultural potential degraded by anthropisation.
\end{abstract}

\section{Subject Areas}

Biodiversity, Ecology, Ecosystem Science, Plant Science

\section{Keywords}

Martinique, Bioclimates, Swietenia, Native Species, Regeneration, Forest, 
Anthropization, Reforestation

\section{Introduction}

The domestication of species for survival and societal development is common to all civilisations [1]. These species have enabled different peoples to ensure their longevity in all living environments [2]. Over ten thousand years ago, the neolithic revolution linked to the birth of agriculture resulting from the gradual or accidental domestication of plants and animals was a turning point in the evolution of humanity [3] [4]. From this period up to today, the transition from subsistence farming to production farming has led to a huge increase in man's impact on ecosystems [5] [6]. With the economic growth of societies and of their demography, what are known as technological plant species relating to the construction, woodworking, carpentry, paper-making and dyeing sectors have been domesticated as well as useful plant food species [7] [8]. On a global scale, the production of some of these plants which can be extremely commercial has led to and still leads to the conversion of natural phytocenoses into agrocenoses: often the species used are allochthonous species [9] [10] [11]. Forestry in tropical and temperate zones, by means of plantation forests, is a significant example [12] [13]. While generating lively debates relating to the global ecological balance, the timber sector is an important component of the global economy and affects the ecosystemic resilience of tropical regions in particular [14]. The Lesser Antilles are also subject to the process of degradation of the original forest environments in favour of exotic tree plantations [15] [16] (Figure 1). In this study, the research protocol is based on transects located in different plots of Mahoganis in order to inventory the populations of autochthonous species [17] [18]. The comparison of native plant species growing under mature Mahoganys plantations and those initiated by nearby natural forests was not considered, due to the fact that the structure of both forest types is very different. Considering the current knowledge, the only tangible data are the various floristic groupings conditioned by Mahogany plantations. Our main objective was to show the impact of the structure of these mature Mahoganis plantation forests in the establishment and development of species of native ligneous flora, especially those from the advanced stages of plant succession.

- What are the ecological factors that condition the natural regeneration of extra- and intra-forest autochthonous species?

- What are the distribution modes of the species populations?

- What are the causes of the qualitative stational differentiation of the species?

\section{Materials}

\subsection{General Bioclimatic Characteristics}

Martinique, like the other Lesser Antilles, stems from an intra-oceanic subduction 


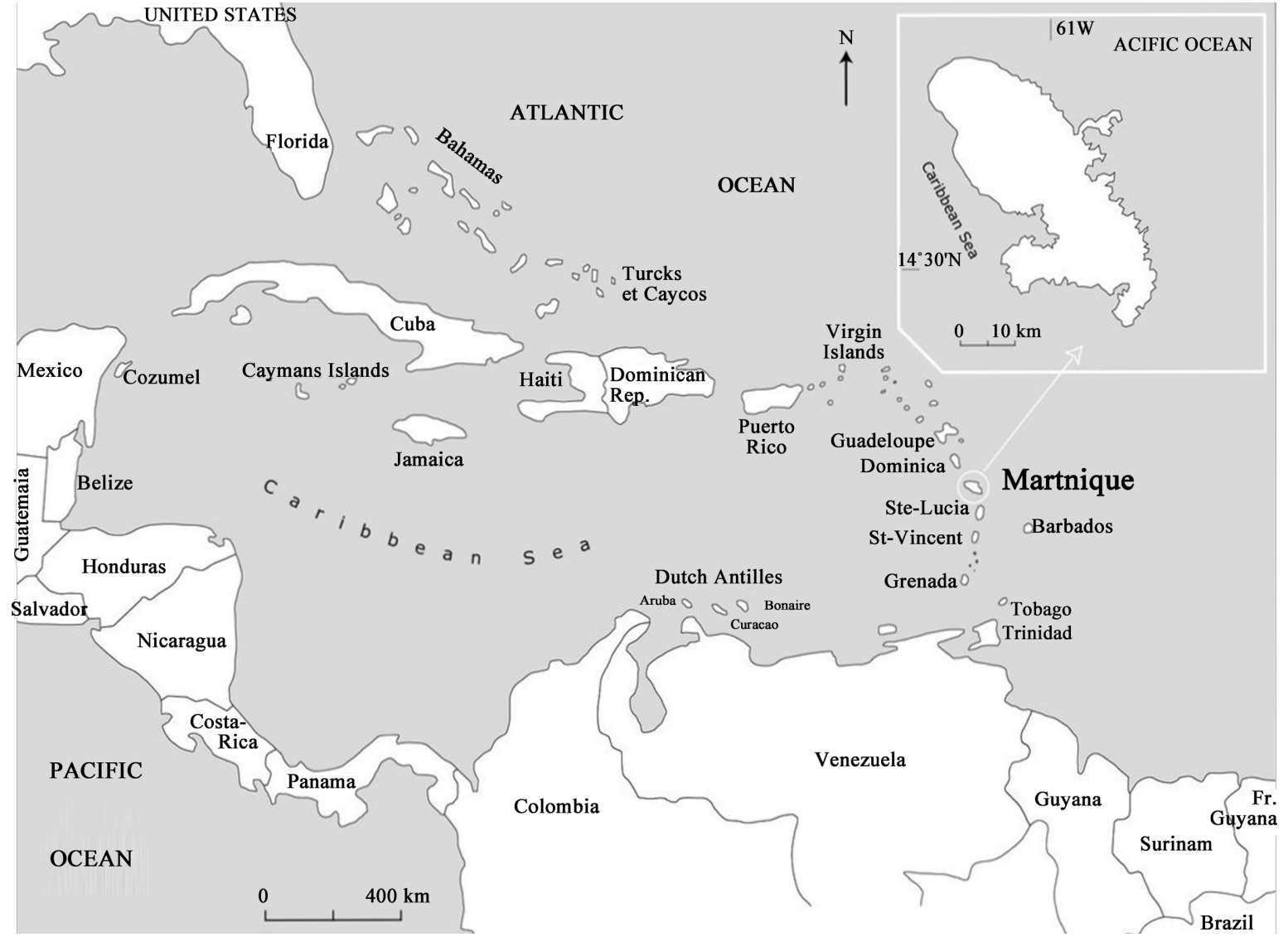

Figure 1. The Lesser Antilles in the Caribbean and survey areas.

which gradually constructed its contrasting geomorphology [19] [20]. The different topographical facies that result from it modify the structure of the main climatic factors and contribute to the considerable diversity of the biotopes. Orographic rain is the key factor of the plant colonisation [21] [22]. This leads to, from the lowlands to the mountain peaks, bioclimates which differ from the altitudinal point of view between the windward slope (eastern slope) and the leeward slope (western slope). This bioclimatic gradient corresponds to a gradient of phytocenotic potential. Indeed, from the littoral to the altitudes, we find in particular: the lower tropical seasonal evergreen forest in its most xeric facies, the typical tropical seasonal evergreen forest, the sub-montane tropical ombrophilous forest and the montane tropical ombrophilous forest. Ecotones allow for the transition between these potential sylvan types. Generally speaking, and regardless of the plant stages, which are therefore bioclimatic, the plant cover is a patchwork of phytocenoses of different structures, specific compositions and ages. Originally, species of the genus Swietenia from Martinique were planted in the bioclimates mentioned above for the production of precious wood.

\subsection{Main Botanical and Phytogeographical Characteristics of the Species of the Genus Swietenia}

From a phylogenetic point of view and in ascending manner, the genus Swiete- 
nia (Jacq.) belongs to the Family of Meliaceae, the Order of Sapindales, the Class of Magnoliopsida (Dycotyledon), the Division of Angiosperms (Magnoliophyta) and the Kingdom Plantae. The Genus Swietenia comprises five species, all native to tropical America ([23] [24] [25] [26]). However, four of them have been introduced into numerous geographic regions of the intertropical zone [27]. Swietenia xaubrevilleana is the result of a hybridisation between macrophylla and mahagoni and is present mainly in certain islands of the archipelago of the Antilles [28] [29] [30]. Swietenia mahagoni, macrophylla and xaubrevilleana are the only species that are present in Martinique. From the morphological point of view, they have a strong resemblance, but aspects pertaining to the foliar unit and the flowers easily differentiate them. In adulthood these trees can peak at 40 metres in height with circumferences at 1.30 metres from the ground ranging from 1.5 to 2.5 metres. Swietenia mahagoni, macrophylla and xaubrevilleana ensure their morphological development on soils conditioned respectively by dry subhumid, humid and humid subhumid bioclimates [17] [31] [32].

\subsection{Study Stations, Edaphoclimatic Factors, Potential Forest Types and Stages of Evolution}

The floristic survey stations were chosen from within mature Mahoganis plantation forests located between $258 \mathrm{~m}$ to $400 \mathrm{~m}$. They are under the influence of hyper-humid, humid and subhumid bioclimates (Table 1(a)) corresponding to a tiering of environmental factors which condition particularly tropical montane, tropical sub-montane and tropical seasonal evergreen phytocenoses respectively. Associated with the different types of vegetation are soils such as andosols, fersiallitic soils and vertisols (Table 1(a) and Table 1(b)). The average annual temperatures measured using meteorological stations close to the floristic survey units vary between $23^{\circ} \mathrm{C}$ and $25^{\circ} \mathrm{C}$ with minimums and maximums of between $20^{\circ} \mathrm{C}$ and $23^{\circ} \mathrm{C}$ and between $27^{\circ} \mathrm{C}$ and $29^{\circ} \mathrm{C}$ (Table 1 (a) and Table 1(b)). The annual rainfall, which is the factor which characterises the bioclimates by influencing the types of plant ecosystems, varies between $2613.1 \mathrm{~mm}$ and $3869.6 \mathrm{~mm}$ with significant seasonal differences (Table 1(a) and Table 1(b)). The number of days with rain during the wet and dry period indicates that the study stations are in rainy areas (Table 1 (a) and Table $1(\mathrm{~b})$ ). The latter are characterised by annual insolation levels and daily global radiation levels which are among the lowest in Martinique (Table 1(a) and Table 1(b)). These aforementioned features are consubstantial with a high annual maximum humidity (100\%) and with an annual evapotranspiration of between $1550 \mathrm{~mm}$ and $1600 \mathrm{~mm}$.

\section{Methods}

The objective of this study is to decipher the structure and functioning of the vegetation which develops under the mature mahogany plots. What corresponds respectively to the distribution of diameters and heights of populations of autochthonous species belonging to the stages of intra-sylvatic succession. Using 
transects subdivided into quadrats and according to the minimum survey area (between 250 to $1050 \mathrm{~m}$; Table 1(b)) we generated data which are both average ecological and floristic descriptors: species, numbers of individuals of populations of plant species [from young regenerations to mature specimens (biodemographic aspects)], diameter classes, classes of total heights and first branchings. All the morphological types were considered during the inventories. But to show the distribution in diameters and in heights, we have retained the shrubs and trees as well as the herbaceous plants with shrub-like habit. The

Table 1. (a) Climatic conditions of the survey stations; (b) Edaphoclimatic conditions and inventory areas of the survey stations.

(a)

\begin{tabular}{|c|c|c|c|c|c|c|c|c|c|}
\hline Stations & Bioclimates & $\begin{array}{l}\text { Altitude } \\
\quad(\mathrm{m})\end{array}$ & $\begin{array}{c}\text { Average } \\
\text { minimum } \\
\text { annual } \\
\text { temperature } \\
\left({ }^{\circ} \mathrm{C}\right)\end{array}$ & $\begin{array}{c}\text { Average } \\
\text { maximum } \\
\text { annual } \\
\text { temperature } \\
\left({ }^{\circ} \mathrm{C}\right)\end{array}$ & $\begin{array}{c}\text { Average } \\
\text { annual } \\
\text { temperature } \\
\left({ }^{\circ} \mathrm{C}\right)\end{array}$ & $\begin{array}{l}\text { Annual } \\
\text { insolation } \\
\text { (number } \\
\text { of hours) }\end{array}$ & $\begin{array}{c}\text { Annual } \\
\text { rainfall } \\
(\mathrm{mm})\end{array}$ & $\begin{array}{l}\text { Average } \\
\text { rainfall for the } \\
\text { three driest } \\
\text { months (mm): } \\
\text { February, } \\
\text { March, April }\end{array}$ & $\begin{array}{c}\text { Average } \\
\text { rainfall for the } \\
\text { three wettest } \\
\text { months }(\mathrm{m}) \text { : } \\
\text { August, } \\
\text { September, } \\
\text { October }\end{array}$ \\
\hline $\begin{array}{c}\text { Sainte-Marie } 1 \\
\text { (S-M1) }\end{array}$ & Humid & 258 & 21.2 & 28.1 & 24 & 2300 & 3869.6 & 500 & 1100 \\
\hline $\begin{array}{c}\text { Sainte-Marie } 2 \\
\text { (S-M2) }\end{array}$ & Humid & 214 & 21.2 & 28.5 & 24 & 2300 & 3812.8 & 500 & 1100 \\
\hline $\begin{array}{l}\text { Laricher } 1 \\
\quad(\mathrm{La}-1)\end{array}$ & Humid & 322 & 21.1 & 28.2 & 24 & 2300 & 3315.6 & 500 & 1000 \\
\hline $\begin{array}{l}\text { Laricher } 2 \\
\quad(\mathrm{La}-2)\end{array}$ & Humid & 193 & 21.7 & 28.7 & 24 & 2300 & 3122.7 & 500 & 1000 \\
\hline $\begin{array}{c}\text { Trou Matelot } \\
\text { (TM) }\end{array}$ & $\begin{array}{l}\text { Hyper } \\
\text { humid }\end{array}$ & 481 & 20.4 & 27.7 & 24 & 2300 & 4213.2 & 600 & 1100 \\
\hline $\begin{array}{l}\text { Gros Morne } 1 \\
\text { (G-M1) }\end{array}$ & Humid & 328 & 20.8 & 28.1 & 25 & 2300 & 3930.8 & 600 & 1100 \\
\hline $\begin{array}{c}\text { Gros Morne } 2 \\
\text { (G-M2) }\end{array}$ & $\begin{array}{l}\text { Hyper } \\
\text { humid }\end{array}$ & 473 & 20.4 & 27.7 & 23 & 2300 & 4213.2 & 600 & 1100 \\
\hline $\begin{array}{l}\text { Montravail } \\
\text { (Mt) }\end{array}$ & $\begin{array}{c}\text { Humid } \\
\text { subhumid }\end{array}$ & 281 & 22.3 & 28.3 & 24 & 2700 & 1965.3 & 200 & 600 \\
\hline $\begin{array}{l}\text { Fond Lahaye } 1 \\
\text { (FL1) }\end{array}$ & $\begin{array}{c}\text { Humid } \\
\text { subhumid }\end{array}$ & 168 & 21.3 & 29.1 & 25 & 2600 & 1748.6 & 300 & 900 \\
\hline $\begin{array}{l}\text { Fond Lahaye } 2 \\
\text { (FL2) }\end{array}$ & $\begin{array}{c}\text { Humid } \\
\text { subhumid }\end{array}$ & 132 & 21.3 & 29.1 & 25 & 2600 & 1748.6 & 300 & 900 \\
\hline $\begin{array}{c}\text { Absalon } 1 \\
(\mathrm{Ab} 1)\end{array}$ & Humid & 443 & 20.2 & 26.8 & 24 & 2400 & 2613.1 & 500 & 1000 \\
\hline $\begin{array}{c}\text { Absalon } 2 \\
(\mathrm{Ab} 2)\end{array}$ & Humid & 387 & 20.2 & 26.8 & 24 & 2400 & 2613.1 & 500 & 1000 \\
\hline $\begin{array}{c}\text { Absalon } 3 \\
(\mathrm{Ab} 3)\end{array}$ & Humid & 400 & 20.2 & 26.8 & 24 & 2400 & 2613.1 & 500 & 1000 \\
\hline
\end{tabular}


(b)

\begin{tabular}{|c|c|c|c|c|c|c|c|c|}
\hline Stations & $\begin{array}{l}\text { Survey } \\
\text { areas } \\
\left(\mathrm{Sr}, \mathrm{m}^{2}\right)\end{array}$ & $\begin{array}{l}\text { Percentage of } \\
\text { days with } \\
\text { significant } \\
\text { rain (Carême } \\
\text { - Lent) }\end{array}$ & $\begin{array}{l}\text { Percentage } \\
\text { of days with } \\
\text { significant } \\
\text { rain } \\
\text { (winter) }\end{array}$ & $\begin{array}{l}\text { Potential annual } \\
\text { evapotranspiration } \\
\text { (mm) }\end{array}$ & $\begin{array}{l}\text { Minimum } \\
\text { monthly } \\
\text { relative } \\
\text { humidity } \\
\text { (\%) }\end{array}$ & $\begin{array}{l}\text { Maximum } \\
\text { monthly } \\
\text { relative } \\
\text { humidity } \\
\text { (\%) }\end{array}$ & $\begin{array}{c}\text { Average } \\
\text { cumulative } \\
\text { daily global } \\
\text { radiation } \\
\left(\text { Joules } / \mathrm{cm}^{2} \text { ) }\right.\end{array}$ & Type of soil \\
\hline $\begin{array}{c}\text { Sainte-Marie } 1 \\
\text { (S-M1) }\end{array}$ & 250 & 50 & 60 & 1550 & 50 & 100 & 55,599 & $\begin{array}{l}\text { Allophanic soils } \\
\text { (Andosols) }\end{array}$ \\
\hline $\begin{array}{c}\text { Sainte-Marie } 2 \\
\text { (S-M2) }\end{array}$ & 525 & 50 & 60 & 1550 & 50 & 100 & 55,599 & $\begin{array}{l}\text { Allophanic soils } \\
\text { (Andosols) }\end{array}$ \\
\hline $\begin{array}{l}\text { Laricher } 1 \\
\quad(\mathrm{La}-1)\end{array}$ & 800 & 50 & 60 & 1550 & 50 & 100 & 55,599 & $\begin{array}{c}\text { Allophanic soils } \\
\text { (Andosols) }\end{array}$ \\
\hline $\begin{array}{l}\text { Laricher } 2 \\
\quad(\mathrm{La}-2)\end{array}$ & 900 & 50 & 60 & 1550 & 50 & 100 & 55,599 & $\begin{array}{c}\text { Brown soils- } \\
\text { Rusty to } \\
\text { Halloysite }\end{array}$ \\
\hline $\begin{array}{l}\text { Trou Matelot } \\
\text { (TM) }\end{array}$ & 1050 & 60 & 70 & 1525 & 50 & 100 & 55,599 & $\begin{array}{l}\text { Allophanic soils } \\
\text { (Andosols) }\end{array}$ \\
\hline $\begin{array}{l}\text { Gros Morne } 1 \\
\text { (G-M1) }\end{array}$ & 480 & 60 & 70 & 1525 & 50 & 100 & 55,599 & $\begin{array}{c}\text { Allophanic soils } \\
\text { (Andosols) }\end{array}$ \\
\hline $\begin{array}{c}\text { Gros Morne } 2 \\
\text { (G-M2) }\end{array}$ & 440 & 60 & 70 & 1525 & 50 & 100 & 55,599 & $\begin{array}{l}\text { Allophanic soils } \\
\text { (Andosols) }\end{array}$ \\
\hline $\begin{array}{c}\text { Montravail } \\
\text { (Mt) }\end{array}$ & 400 & 30 & 50 & 1600 & $(-)$ & $(-)$ & $(-)$ & Fersiallitic soils \\
\hline $\begin{array}{l}\text { Fond Lahaye } 1 \\
\text { (FL1) }\end{array}$ & 700 & 40 & 50 & 1700 & 48 & 100 & 53,720 & Vertisols \\
\hline $\begin{array}{c}\text { Fond Lahaye } 2 \\
\text { (FL2) }\end{array}$ & 1000 & 40 & 50 & 1700 & 48 & 100 & 53,720 & Vertisols \\
\hline $\begin{array}{l}\text { Absalon } 1 \\
\text { (Ab1) }\end{array}$ & 700 & 50 & 60 & 1600 & 48 & 100 & 53,720 & $\begin{array}{l}\text { Allophanic soils } \\
\text { (Andosols) }\end{array}$ \\
\hline $\begin{array}{c}\text { Absalon } 2 \\
\text { (Ab2) }\end{array}$ & 700 & 50 & 60 & 1600 & 48 & 100 & 53,720 & $\begin{array}{c}\text { Allophanic soils } \\
\text { (Andosols) }\end{array}$ \\
\hline $\begin{array}{c}\text { Absalon } 3 \\
\text { (Ab3) }\end{array}$ & 900 & 50 & 60 & 1600 & 48 & 100 & 53,720 & $\begin{array}{c}\text { Allophanic soils } \\
\text { (Andosols) }\end{array}$ \\
\hline
\end{tabular}

minimum area corresponds to the minimum area within which the inventoried floristic sample can be considered as statistically representative of the studied environment.

These features allowed us:

- to assess the distribution of the sections of the individuals, the architecture of the formations, the characteristics of the canopies.

- to evaluate the phytomasses or biovolumes using the basal area (St) which corresponds to the sum of the cross-sectional areas of the trees measured at 1.30 metres from the ground in accordance with international standards. For all the individuals of a station, the total basal area corresponds to the sum of 
the individual basal areas.

- to find out the distribution of the species between the quadrats of the transects and between the stations using the Index of distribution which corresponds to the following formula: $\mathrm{Id}=\mathrm{FR} \times \mathrm{d}$ (FR being the relative frequency and $\mathrm{d}(\mathrm{nb} / \mathrm{Sr})$ the density corresponding to the number of individuals of the species (nb) divided by the survey area (Sr, Table $1(\mathrm{~b})$ ).

- to discover the relative dominance of ligneous plant species in relation to each other via the Index of Dominance (ID). ID $=\mathrm{Id} \times \mathrm{St}$ (basal area).

- to conduct a Correspondence Factor Analysis (CFA) and an Ascending Hierarchical Classification (AHC) from the XLSTAT software (2019 version), which allowed us to compare the stations with one another with regard to the population structures of the different species.

\section{Results}

\subsection{Taxonomic Diversity of Naturally-Regenerating Flora under Mahoganys Plantation}

With 63 families, 113 genera and 117 species, the taxonomic richness of the flora regenerating under the Mahoganys plantations taken as a reference is quite significant. However, the distributions within the different stations differ. The following families are the most distributed: Arecaceae, Boraginaceae, Burseraceae, Clusiaseae, Cyatheaceae, Cyclanthaceae, Dichapetalaceae, Elaeocarpaceae, Fabaceae, Heliconiaceae, Lauraceae, Magnoliaceae, Malvaceae, Melastomataceae, Meliaceae, Myrtaceae, Piperaceae, Poaceae, Rubiaceae, Sapotaceae, Simaroubaceae and Solanaceae. The generic richness of the families is high over all the thirteen inventory stations and the most represented genera are twenty in number or 17.7\%: Aniba, Asplundia, Cestrum, Chimarrhis, Cyathea, Dacryodes, Eugenia, Heliconia, Miconia, Myrcia, Ocotea, Palicourea, Piper, Pouteria, Psychotria, Simaruba, Sloanea, Swietenia, Talauma and Tapura. Specific diversity is also significant with a small number of species having a Relative Frequency (FR= number of occurrences over all stations) of at least 50\% (16.24\%) throughout the 13 study plots: Aniba bracteata, Asplundia rigida, Cestrum laurifolium, Chimarrhis cymosa, Clidemia umbrosa, Cordia sulcata, Cyathea arborea, Cyathea muricata, Dacryodes excelsa, Heliconia caribaea, Miconia trichotoma, Myrcia fallax, Palicourea crocea, Piper dilatatum, Pouteria pallida, Simarouba amara, Swietenia macrophylla, Talauma dodecapetala (Magnolia dodecapetala) and Tapura latifolia.

\subsection{Structural and Architectural Characteristics of the Naturally-Regenerating Indigenous Flora under Mahoganys Plantation}

\subsubsection{General Structure of Natural Regeneration over All Stations}

Under the plantation forests of the study stations, the set of ligneous individuals, including shrubs and trees presenting various development stages, mostly have, at $1.33 \mathrm{~cm}$ from the ground, trunk diameters of $2.5 \mathrm{~cm}$ (Figure 2(a)). Regarding the number of individuals per diameter class, the reduction factor is 3.74 among 

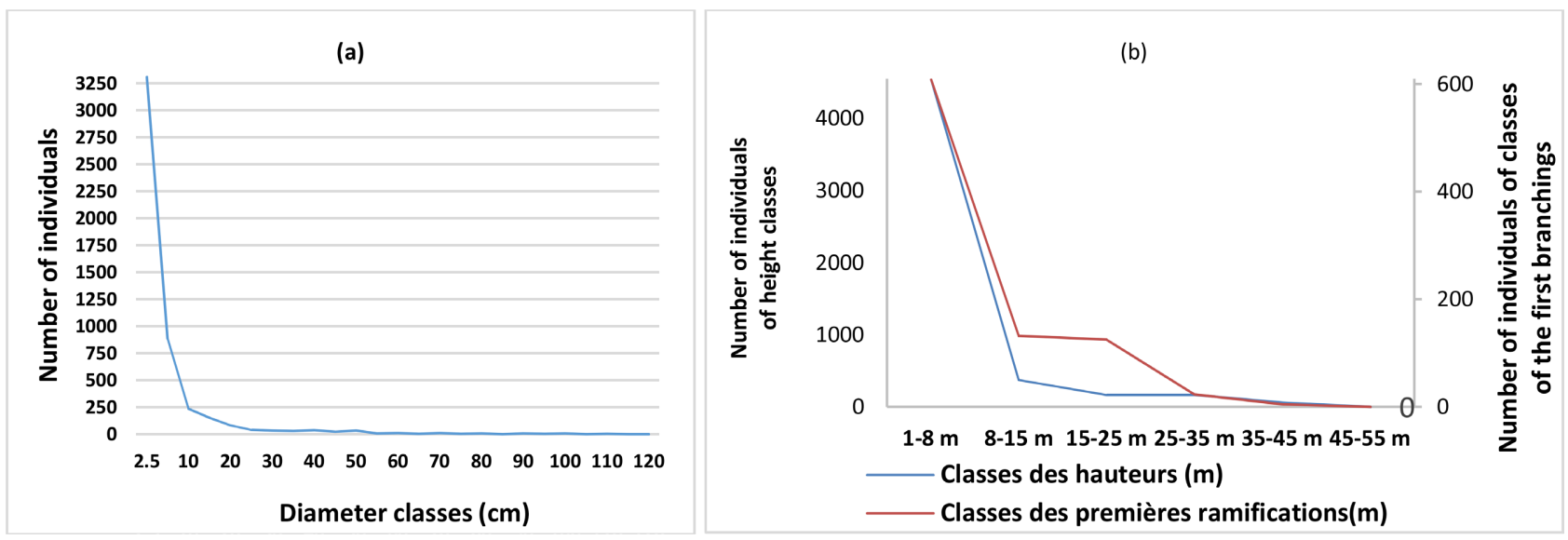

Figure 2. Distribution of autochthonous populations by class of diameters (a), heights (b) and first branchings (b).

the populations of autochthonous species between $2.5 \mathrm{~cm}$ and $5 \mathrm{~cm}$ classes, while the reduction factors are 13.9 and 21.8 between the $2.5 \mathrm{~cm}$ class and those of $10 \mathrm{~cm}$ and $15 \mathrm{~cm}$ respectively. As shown in Figure 2(a), for classes with a diameter greater than $15 \mathrm{~cm}$ the number of stems is between 39 and 663 times lower than that of the $2.5 \mathrm{~cm}$ class. Similar decreasing curves are observed for heights and first branchings (Figure 2(b)) where the quantitative differences are significant among the classes of heights and first branchings. The reduction factors between the 1-8 $\mathrm{m}$ height class and the $8-15 \mathrm{~m}, 15-25 \mathrm{~m}, 25-35 \mathrm{~m}, 35$ $45 \mathrm{~m}$ and $45-55 \mathrm{~m}$ height classes are $12,26.8,26.8,77$ and 4535 respectively (Figure 2(b)). The phenomenon is similar concerning the first branchings of which the quantitative reduction factors among the $1-8 \mathrm{~m}$ class and the $8-15$ $\mathrm{m}, 15-25 \mathrm{~m}, 25-35 \mathrm{~m}$ and $35-45 \mathrm{~m}$ classes are 4.6, 4.86, 26.4 and 121.6 (Figure 2(b)).

\subsubsection{Specific Demographic Structures over All Stations}

The specific demographic structure show significant variations both in terms of the numbers of all the diameter classes and in terms of the numbers of each diameter class. Individuals with $2.5 \mathrm{~cm}$ diameter are the majority and involve a small percentage of species, in particular those whose number of stems is at least fifty, all stations combined: Aniba bracteata, Cestrum laurifolium, Myrcia fallax, Myrcia splendens, Palicourea crocea, Pimenta racemosa, Piper dilatatum, Pouteria multiflora, Psychotria mapourioides, Psychotria muscosa, Swietenia macrophylla, Talauma dodecapatala, Tapura latifolia, Trichilia septentrionalis. Therefore, the dominant species represented by more than 100 individuals overall are marginal and are the following: Aniba bracteata, Cestrum laurifolium, Chimarrhis cymosa, Myrcia fallax, Myrcia splendens, Palicourea crocea, Pimenta racemosa, Piper dilatatum, Pouteria multiflora, Psychotria muscosa, Swietenia macrophylla, Swietenia xaubrevilleana, Tapura latifolia, Trichilia septentrionalis. It should also be noted that certain autochthonous species such as Cecropia schreberiana, Coccoloba swartzii, Cyathea arborea, Dacryodes excelsa, Guatteria caribaea, Inga laurina, Sloanea dentata and Sloanea massoni have a small number 
of representatives in several diameter classes.

The distribution of species populations according to height class seems to follow the same trend as that observed for diameter class. Indeed, the majority of individuals have a height of between $1 \mathrm{~m}$ and $8 \mathrm{~m}$ and correspond to a number of taxa, particularly those whose number of specimens is greater than 50 . Chimarrhis cymosa, Cyathea arborea, Cyathea muricata, Dacryodes excelsa, Guatteria caribaea, Heliconia caribaea, Myrcia fallax, Myrcia splendens and Pouteria pallida are the species that differ from those of the majority group composed of individuals ranked into the $2.5 \mathrm{~cm}$ diameter class and represented by at least 50 individuals. Logically, the majority of the first branchings are between $1 \mathrm{~m}$ and 8 m. However, a low number of individuals of a few species have their first branchings in greater height classes.

\section{Distribution and Ecological Dominance of Species over All Stations}

The Index of distribution (Id) of the species across the thirteen floristic survey stations results from the product of their relative frequency (FR) and the density (d) of their individuals (see Methods section). This Id shows the mode of population distribution of the various regenerating species throughout the inventory areas and indicates the types of sociability ranging from dispersed to gregarious. Figure 3 shows the interspecies variation of the three aforementioned indicators. There seems to be a certain parallelism of the curves. The Relative Frequency (FR) curve indicates that the majority of species are on average present in $30 \%$ of the stations, i.e. around four. The taxa whose relative frequency is greater than 60\% are the following: Aniba bracteata, Chimarrhis cymosa, Cestrum laurifolium, Cyathea arborea, Cyathea muricate, Dacryodes excelsa, Miconia trichotoma, Myrcia fallax, Palicourea crocea, Piper dilatatum, Pouteria pallida, Simarouba amara, Talauma dodecapetala and Tapura latifolia. In general, apart from Tapura latifolia whose density of individuals is relatively higher, the density of regenerating populations is low and even very low for certain species (Figure 3 ). This leads to Indices of distribution (Id) which are also low to very low. At the level of the thirteen inventory plots, the most distributed species with an Id greater than or equal to 0.015 are, in descending order of significance: Tapura latifolia-131, Swietenia macrophylla-127, Myrcia fallax-85, Palicourea crocea-94, (Figure 3).

Despite the low distribution of species characterised by the Id, it was necessary to determine their ecological significance using the Index of Dominance (ID). Tapura latifolia, Chimarrhis cymosa and Dacryodes excelsa are, in descending order of significance, the three dominant species with respect to the set of survey stations (Table 2). Unlike Chimarrhis cymosa and Dacryodes excelsa where the total Basal Area (ST) and ID are respectively $3.66-0.0115$ and $2.93-0.007, \mathrm{Ta}$ pura latifolia has an ST of 0.84 and an ID of 0.06 . These aspects are related to the distribution of the diameter classes and therefore the age classes for each species. 
For the other species, the dominance index values are 103 to 109 times lower. This reflects the low densities of populations of autochthonous species in regeneration and their incomplete growth development.

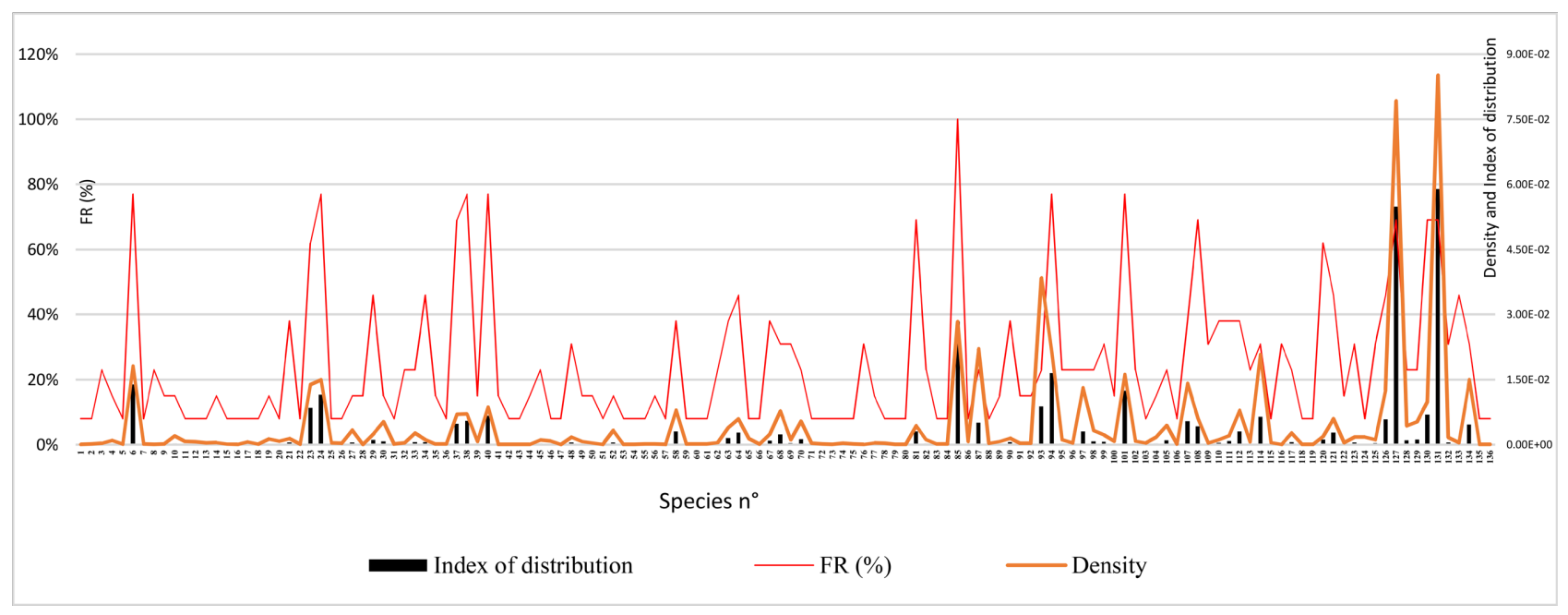

Figure 3. Specific variation of the Relative Frequency, density and Index of distribution [herbaceous and ligneous types (bushes, trees and lianas) $/ F R=F A \div 13$ (Stations)/FA: Absolute Frequency corresponding to the number of species present, all survey stations combined $/ \mathrm{d}=$ number of individuals per $\mathrm{m}^{2}$ (total area of the thirteen stations). $\mathrm{Id}=\mathrm{FR} \times \mathrm{d}$.

Acacia retusa-1/Aiphanes luciana?-2/Aiphanes minima-3/Aiphanes sp-4/Andira inermis-5/Aniba bracteata-6/Artocarpus altilis var. non seminifera-7/Asplundia insignis-8/Bambusa multiplex-9/Bambusa vulgaris-10/Beilschmiedia pendula-11/Besleria luthea-12/Bourreria succulent-13/Brosimum alicastrum-14/Bunchosia polystachia-15/Bursera simaruba-16/Callophyllum calaba-17/Capparis baducca-18/Casearia decandra-19/Cassipourea guianensis-20/Cecropia schreberiana-21/Cedrela odorata -22/Cestrum laurifolium-23/Chimarrhis cymosa-24/Chiococca alba-25/Chionanthus compacta-26/Chrysophyllum argenteum-27/Clidemia hirta-28/Clidemia umbrosa-29/Coccoloba swartzii-30/Coffea liberica-31/Conostegia calyptrata-32/Conostegia icosandra-33/Cordia sulcata-34/Costus afer-35/Croton corylifolius-36/Cyathea arborea-37/Cyathea muricata-38/Cyathea tenera-39/Dacryodes excels-40/Dalbergia monetaria-41/Drypetes glauca-42/Erythroxylon havanense-43/Eugenia albicans-44/Eugenia duchassaingiana-45/Eugenia monticola-46/Eugenia oerstedeana-47/Eugenia pseudopsidium-48/Eugenia trinervia-49/Faramea occidentalis-50/Ficus citrifolia-51/Funtumia elastica-52/Garcinia humilis-53/Genipa Americana-54/Gonzalagunia hirsuta-55/Guarea kunthiana-56/Guarea sp-57/Guatteria caribaea-58/Guazuma tomentosa-59/Haematoxylon campechianum-60/Hedyosmum arborescens-61/Heisteria coccinea-62/Heliconia bihai-63/Heliconia caribaea-64/Heliconia sp-65/Ilex nitida-66/Inga ingoïdes-67/Inga laurina-68/Lxora ferrea-69/Licania ternatensis-70/Lonchocarpus heptaphyllus-71/Lonchocarpus punctatus -72/Macfadyena unguis cati-73/Mangifera indica-74/Manilkara bidentate-75/Marcgravia umbellate-76/Marila racemosa-77/Maytenus guianensis-78/Maytenus laevigata-79/Miconia mirabilis-80/Miconia trichotoma-81/Micropholis guyanensis-82/Myrcia citrifolia-83/Myrcia deflexa-84/Myrcia fallax-85/Myrcia leptoclada-86/Myrcia splendens-87/Ocotea coriacea-88/Ocotea eggersiana-89/Ocotea leucoxylon-90/Ocotea membranacea-91/Ocotea patens-92/Odontonema nitidum-93/Palicourea crocea-94/Petrea kohautiana-95/Picramnia pentandra-96/Pimenta racemose-97/Piper aduncum-98/Piper aequale-99/Piper amalago-100/Piper dilatatum-101/Piper dussii-102/Piper hispidum-103/Piper reticulatum -104/Pisonia fragans-105/Plinia pinnata-106/Pouteria multiflora-107/Pouteria pallida-108/Pouteria semecarpefolia-109/Prestoea montana-110/Psychotria berteriana-111/Psychotria mapourioides-112/Psychotria microdon-113/Psychotria muscosa-114/Psychotria nervosa-115/Psychotria uliginosa-116/Quararibea turbinata-117/Randia aculeata-118/Sapium caribaeum-119/Simarouba amara-120/Sloanea dentata-121/Sloanea dussii-122/Sloanea massoni-123/Sloaena sp-124/Sterculia caribaea-125/Swietenia xaubrevilleana-126/Swietenia macrophylla-127/Swietenia mahagoni-128/Tabernaemontana citrifolia-129/Talauma dodecapetala -130/Tapura latifolia-131/Tovomita plumieri-132/Trichilia pallida-133/Trichilia septentrionalis-134/Vitex divaricate-135/Xylosma martinicensis-136. 


\section{Mature Trees of Natural Flora}

To explain the presence of relict trees in the old-growth study stations, several hypotheses are possible:

a) Although they have different dendrometric characteristics (in particular diameters and heights of mature specimens), adult trees with DBH between $60 \mathrm{~cm}$ and $120 \mathrm{~cm}$ and heights greater than $25 \mathrm{~m}$ are typical components of old-growth natural forests.

a1) It is highly plausible that these relict trees were structuring elements of the upper strata of these phytocenoses in the past.

a2) For unexplained reasons, the latter have escaped deforestation prior to the establishment of pure plantations of Mahoganys (Figure 4). Either these trees were at the edge of the planted plots or the deforestation was selective for the benefit of construction, carpentry and woodworking activities.

Trees with DBH between $20 \mathrm{~cm}$ and $55 \mathrm{~cm}$ and heights less than $25 \mathrm{~m}$ are either mature (regardless of what strata they belong to) or are at different stages of growth (Figure 5).

Table 2. Distribution and dominance indices and basal areas (All inventory areas combined).

\begin{tabular}{cccc}
\hline Species & index of distribution & $\begin{array}{c}\text { Total basal area } \\
\text { by species }\left(\mathrm{m}^{2}\right)\end{array}$ & $\begin{array}{c}\text { Indice de } \\
\text { dominance }\end{array}$ \\
\hline Swietenia macrophylla & 0.054884246 & 18.76622963 & 1.02997037 \\
Swietenia xaubrevilleana & 0.005785519 & 15.68479063 & 0.09074465 \\
Tapura latifolia & 0.058949746 & 0.843266625 & 0.04971035 \\
Chimarrhis cymosa & 0.011553664 & 3.659199 & 0.04227715 \\
Dacryodes excelsa & 0.006688963 & 2.927559375 & 0.01958234 \\
\hline
\end{tabular}

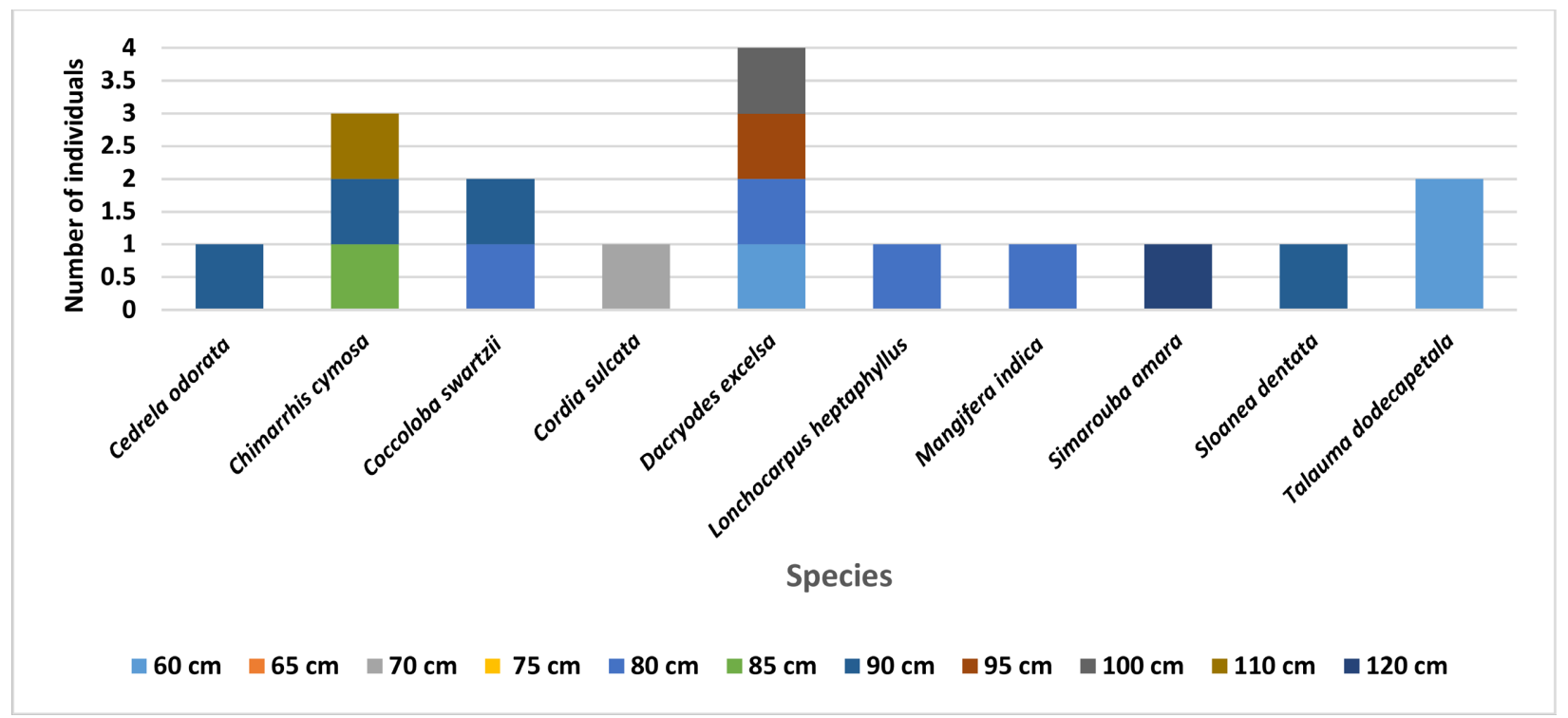

Figure 4. Number of individuals per diameter class in adult trees of relict species from old forest matrices or windthrows(All inventory areas combined). 


\section{Topographic and Bioclimatic Differentiations Depending on the Stations and Species}

The Correspondence Factor Analysis (CFA) based on a 2-way contingency table composed of 136 species (rows) and 13 inventory stations (columns) shows that there is a link between these two categorical variables ( $p$-value $=0.0001$ ). Axes F1 and F2 (total inertia: 38.70\%) of Figure 6(a) distinguish between stations both at bioclimatic and taxonomic levels: stations with humid bioclimates [SM1, SM2, GM1, GM2, La1, La2, Ab1, Ab2, Ab3, TM, MT (as defined in Table 1)] and stations with subhumid bioclimates [FL1, FL2]. The different groups of

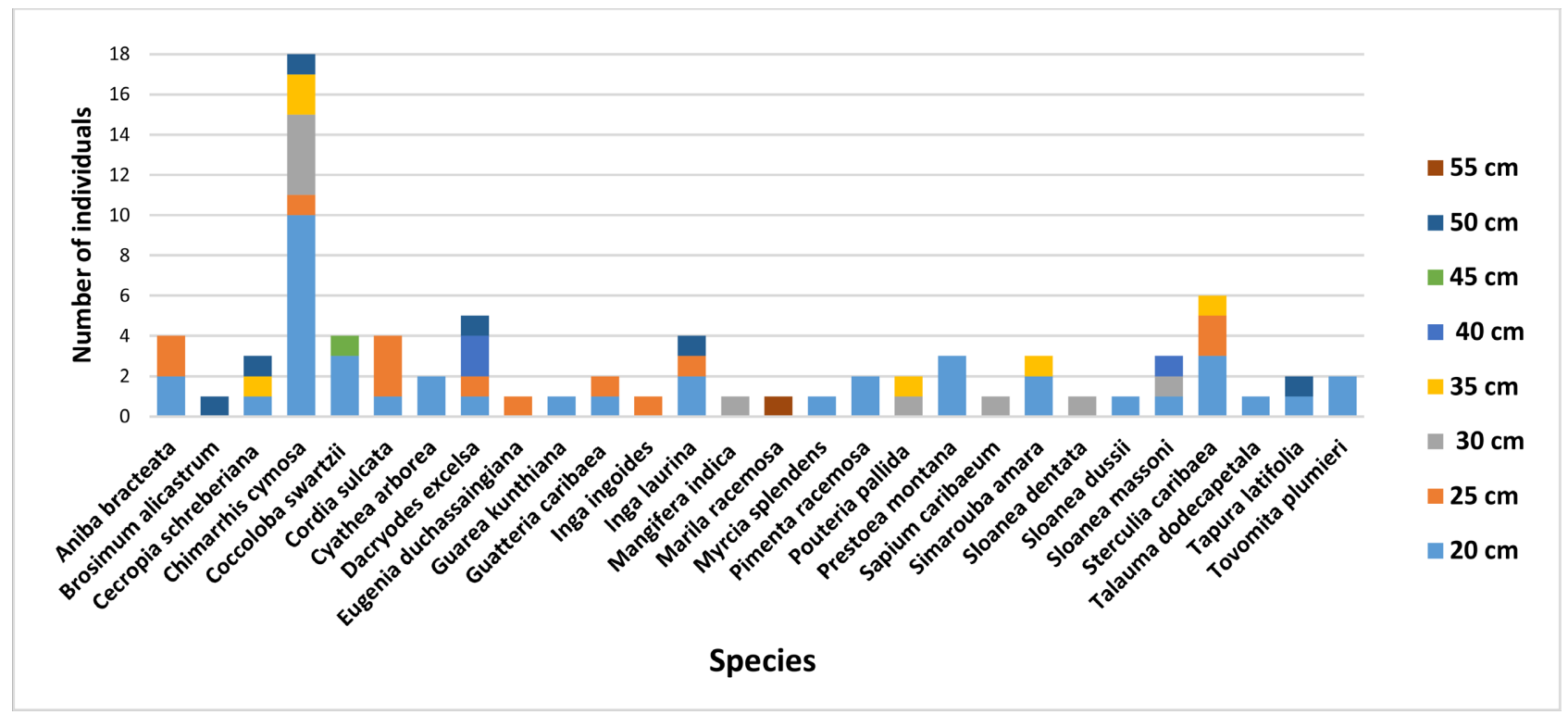

Figure 5. Number of individuals per diameter class in forest matrix or gap trees (All inventory areas combined).

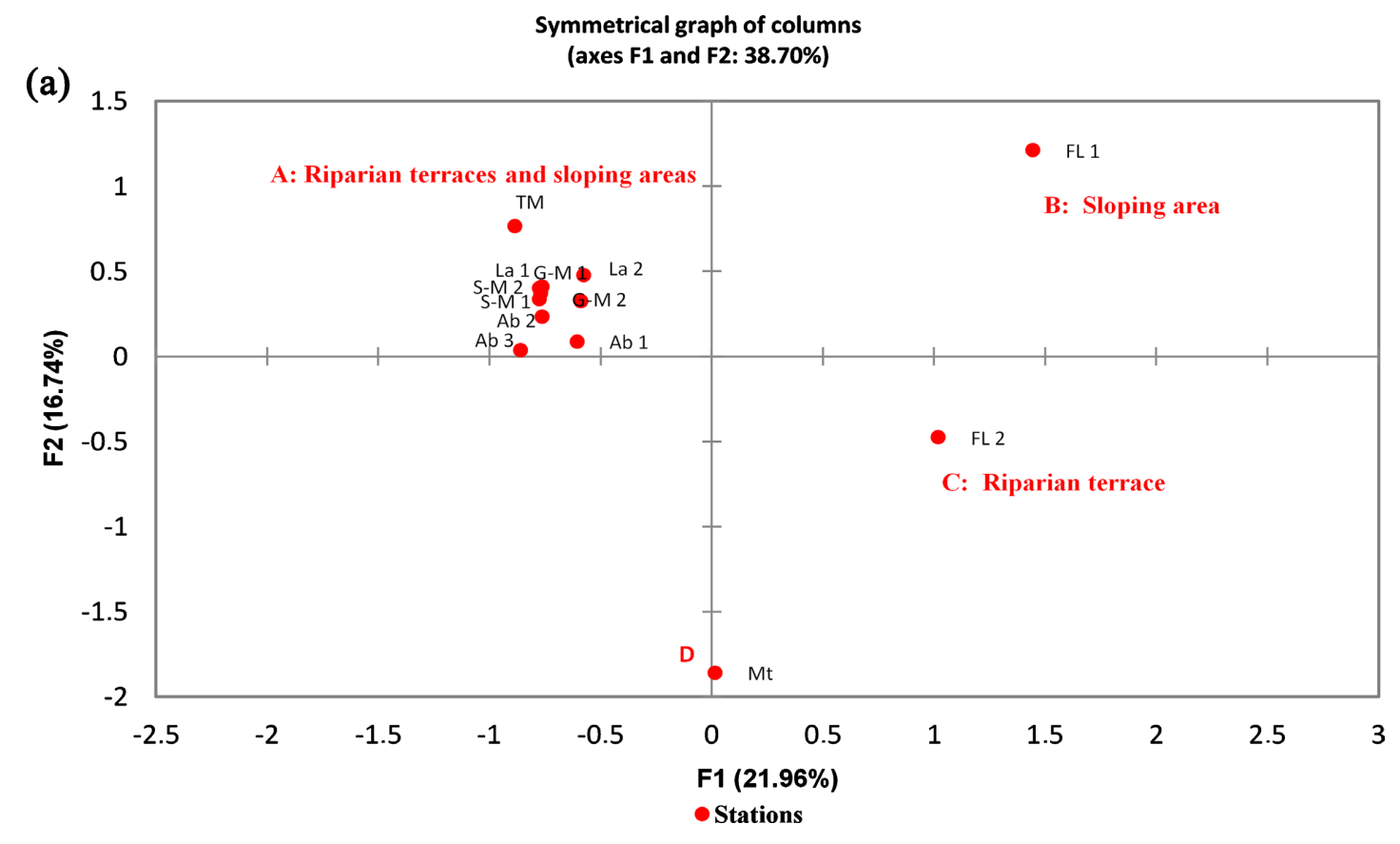




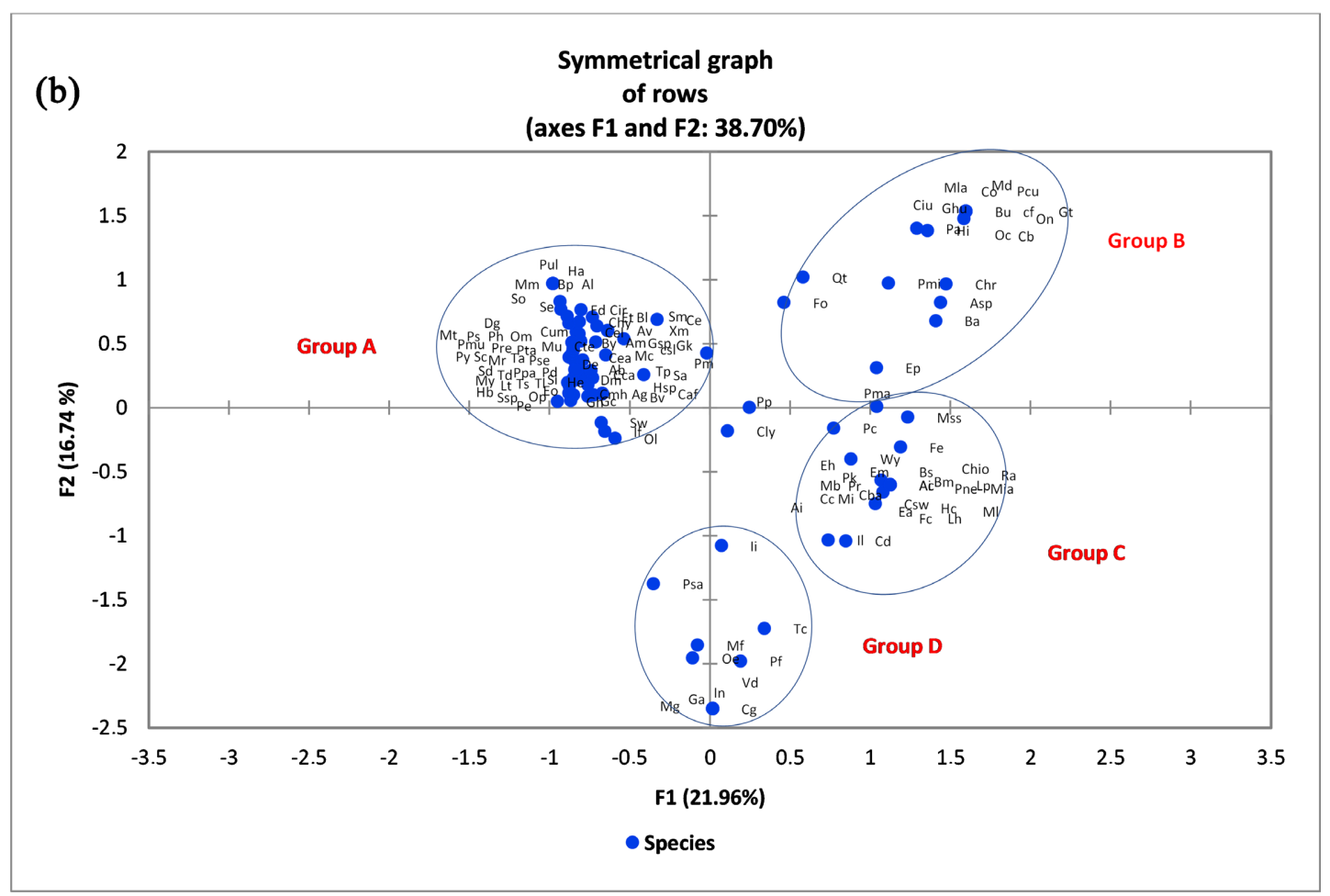

Figure 6. (a) Bioclimatic affinities of the stations (see Table 1 for abbreviations references); (b) Ecosystemic affinity of the species (see Box 1 below for abbreviations references).

Box 1

Group A: Pul (Psychotria uliginosa), Ha (Hedyosmum arborescens), Mm (Miconia mirabilis), Bp (Beilschmiedia pendula), Al (Aiphanes luciana ?), So (Swietenia mahagoni), Se (Sterculia caribaea), Dg (Drypetes glauca), Mt (Miconia trichotoma), Ps (Piper dussii), Ph (Piper hispidum), Om (Ocotea membranacea), Cum (Clidemia umbrosa), Pmu (Pouteria multiflora), Pre (Prestoea montana), Pta (Plinia pinnata), Mu (Marcgravia umbellata), Py (Psychotria berteriana), Sc (Sapium caribaeum), Mr (Marila racemosa), Ta (Trichilia pallida), Pse (Pouteria semecarpifolia), Sd (Sloanea dentata), Td (Talauma dodecapetala), Ppa (Pouteria pallida), Pd (Piper aduncum), My (Micropholis guyanensis), Lt (Licania ternatensis), Ts (Trichilia septentrionalis), Tl (Tapura latifolia), Si (Sloanea dussii), Hb (Heliconia bihai), Ssp (Sloanea sp), Op (Ocotea patens), Eo (Eugenia oerstedeana), Pe (Piper aequale), Ed (Eugenia duchassaingiana), Cir (Conostegia icosandra), Et (Eugenia trinervia), Bl (Besleria luthea), Sm (Sloanea massoni), Ce (Cecropia schreberiana), Chy (Chimarrhis cymosa), $\mathrm{Cel}$ (Cestrum laurifolium), Av (Artocarpus altilis var. non seminifera), Xm (Xylosma martinicensis), Cea (Cyathea arborea) Cte (Cyathea tenera), By (Bunchosia polystachia), Am (Aiphanes minima), Gsp (Guarea sp), Gk (Guarea kunthiana), Cls (Cordia sulcata), Cca (Cyathea muricata), Mc (Macfadyena unguis cati), Pm (Piper dilatatum), De (Dacryodes excelsa), Ab (Aniba bracteata), Tp (Tovomita plumieri), Sa (Simarouba amara), He (Heisteria coccinea), Dm (Dalbergia monetaria), Hsp (Heliconia sp), Caf (Costus afer), Cmh (Clidemia hirta), Ag (Asplundia insignis), Bv (Bambusa vulgaris), Ghu (Gonzalagunia hirsuta), Gc (Guatteria caribaea), Sw (Swietenia xaubrevilleana), If (Ixora ferrea), $\mathrm{Ol}$ (Ocotea leucoxylon)/

Group B: Mla (Myrcia leptoclada), Co (Cedrela odorata), Md (Myrcia deflexa), Pcu (Piper reticulatum), Ciu (Croton corylifolius), Gh (Garcinia humilis), Bu (Bursera simaruba), Cf (Coffea liberica), On (Odontonema nitidum), Gt (Guazuma tomentosa), $\mathrm{Pa}$ (Piper amalago), Hi (Heliconia caribaea), Oc (Ocotea coriacea), Cb (Capparis baducca), Qt (Quararibea turbinata), Pmi (Psychotria microdon), Chr (Chrysophyllum argenteum), Fo (Faramea occidentalis), Asp (Aiphanes sp), Ba (Brosimum alicastrum), Ep (Eugenia pseudopsidium), Pma (Psychotria mapourioides)/

Group C: Ai (Andira inermis), Mss (Myrcia splendens), Pc (Palicourea crocea), Fe (Funtumia elastica), Wy (Swietenia macrophylla), Chio (Chionanthus compacta), Ra (Randia aculeata), Eh (Erythroxylon havanense), Em (Eugenia monticola), Bs (Bourreria succulenta), Bm (Bambusa multiplex), Pne (Psychotria nervosa), Lp (Lonchocarpus punctatus), Mia (Myrcia citrifolia), Pk (Petrea kohautiana), Ac (Acacia retusa), Mb (Manilkara bidentata), $\operatorname{Pr}$ (Pimenta racemosa), Cc (Callophyllum calaba), Mi (Mangifera indica), Cba (Chiococca alba), Csw (Coccoloba swartzii), Hc

(Haematoxylon campechianum), Ea (Eugenia albicans), Fc (Ficus citrifolia), Lh (Lonchocarpus heptaphyllus), Ml (Maytenus laevigata), Il (Inga laurina), Cd (Casearia decandra) /

Group D: li (Inga ingoides), Psa (Psychotria muscosa), Tc (Tabernaemontana citrifolia), Mf (Myrcia fallax), Oe (Ocotea eggersiana), $\operatorname{Pf}($ Pisonia fragrans), Vd (Vitex divaricata), In (Ilex nitida), Ga (Genipa americana), Cg (Cassipourea guianensis), Mg (Maytenus guianensis). Pp (Picramnia pentandra) is a species common to stations $F 2$ and La-2/Cly (Conostegia calyptatra) is a naturally-regenerating species common to stations G-MR, Ab3 and $F 2$ 
species can be affiliated to the following forest categories (Figure 6(b)): tropical sub-montane ombrophilous forest (Group A), tropical ombro-evergreen forest (Group D), tropical evergreen forest [Group B (Sloping area) and Group C (Riparian terrace)]. The distances between the species segregated by the first two factorial axes correspond to various degrees of similarity between their biodiversity structures. Within groups A, B, C and D, the Relative Frequencies (FR) and the densities (d) of the species are appreciably similar while between these groups the specific differences (of the taxa) with regard to these indicators (FR and d) are pronounced.

The FL1, FL2 and Mt stations differ from the others from a floristic point of view, so that we have removed them from the contingency table. A new Correspondence Factor Analysis concerning only the stations influenced by the humid bioclimate (Group A, Figure 6(a)) was carried out based on the new contingency table of 89 rows (Species) and 10 columns (Stations). The different positions of these humid stations on the plane defined by the first two factorial axes of Figure 7(a) are related to their corteges of species in regeneration. It seems that each station is characterised by a phytocenosis of which certain taxa are highly specific. In reality, the degrees of taxonomic difference correspond to more or less significant distances between the stations presented on the plane formed by the factorial axes F1 and F2 (Figure 7(a)). As for the variations in distance between taxa (Figure 7(b)), they result from their differences in populational structures. These are related to the minimum survey areas (Table 1). The combinations of species (I, II, III, IV, V, Figure 7(b)) which distinguish the study stations are just particular phytocenotic expressions of the tropical ombro-evergreen and submontane ombrophilous forest vegetation.

Two Ascending Hierarchical Classifications (AHC) based on general similarity were carried out based on the set of the stations (13) and their species (136).
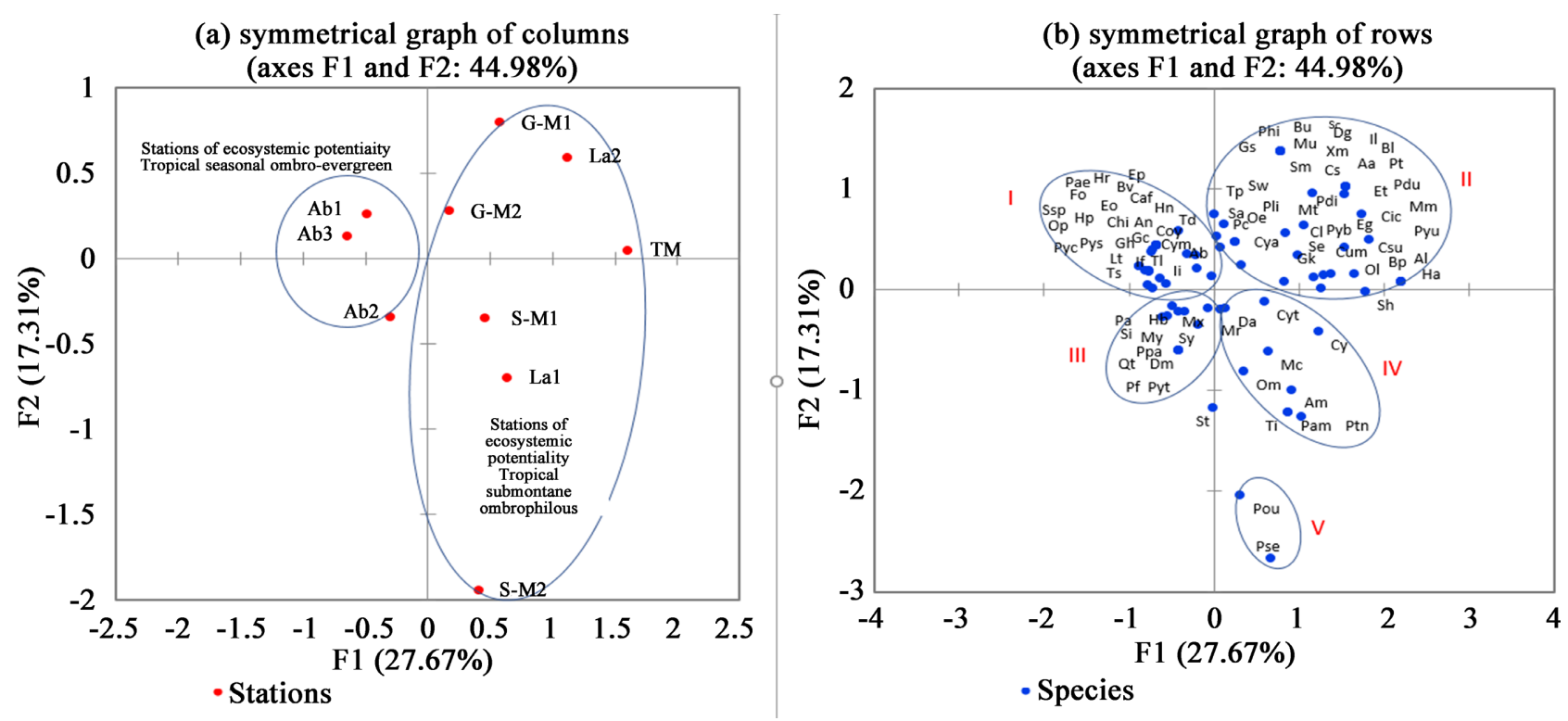

Figure 7. Biodemographic differentiation [(a) Stational, (b) Specific (Box 2)]. 
Box 2

Group I: Pae (Piper aequale), $\mathrm{Hr}$ (Heliconia caribaea), Ep (Eugenia pseudopsidium), BV (Bambusa vulgaris), Fo (Faramea occidentalis), Caf (Costus afer), Ssp (Sloanea sp), Eo (Eugenia oerstedeana), Hn (Heisteria coccinea), Hp (Heliconia sp), Chi (Clidemia hirta), An (Asplundia insignis), Td (Talauma dodecapetala), Op (Ocotea patens), Coy (Conostegia calyptatra), Pyc (Psychotria muscosa), Pys (Psychotria mapourioides), Gh (Garcinia humilis), Gc (Guatteria caribaea), Cym (Cyathea muricata), Ab (Aniba bracteata), Lt (Licania ternatensis), If (Ixora ferrea), Tl (Tapura latifolia), Ts (Trichilia septentrionalis), Ii (Inga ingoides).

Group II: Pa (Piper aduncum,) Hb (Heliconia bihai), Mx (Myrcia fallax), Si (Sloanea dussii), My (Micropholis guyanensis), Sy (Swietenia macrophylla), Ppa (Pouteria pallida), Qt (Quararibea turbinata), Dm (Dalbergia monetaria), Pf (Pisonia fragrans), Pyt (Psychotria microdon)

Group III: Phi (Piper hispidum), Bu (Bunchosia polystachia), Sc (Sapium caribaeum), Dg (Drypetes glauca), Gs (Guarea sp), Mu (Marcgravia umbellata), Xm (Xylosma martinicensis), II (Inga laurina), BI (Besleria luthea), Sm (Sloanea massoni), Cs (Cecropia schreberiana), Aa (Artocarpus altilis var. non seminifera), Pt (Picramnia pentandra), Tp (Tovomita plumieri), SW (Swietenia xaubrevilleana), Pdi (Piper dilatatum), Et (Eugenia trinervia), Pdu (Piper dussii), Pli (Plinia pinnata), Mt (Miconia trichotoma), Mm (Miconia mirabilis), Sa (Simarouba amara), Oe (Ocotea eggersiana), Pc (Palicourea crocea), Eg (Eugenia duchassaingiana), Cic (Conostegia icosandra), Cl (Cestrum laurifolium), Pyb (Psychotria berteriana), Pyu (Psychotria uliginosa), Cya (Cyathea arborea), Se (Sterculia caribaea), Cum (Clidemia umbrosa), Csu (Cordia sulcata), Gk (Guarea kunthiana), Al (Aiphanes luciana), Bp (Beilschmiedia pendula), Ol (Ocotea leucoxylon), Ha (Hedyosmum arborescens), Sh (Swietenia mahagoni)

Group IV: Mr (Marila racemosa), Da (Dacryodes excelsa), Cyt (Cyathea tenera), Om (Ocotea membranacea), Mc (Macfadyena unguis cati), Cy (Chimarrhis cymosa), Am (Aiphanes minima), Pam (Piper amalago), Ptn (Prestoea montana)

Group V: Pou (Pouteria multiflora), Pse (Pouteria semecarpifolia), St (Sloanea dentata) is a regenerating species common to stations $S M 1, A b 2$ and La1

The AHC graphs obtained highlight many distinguishing features both between stations and between species. First, from the set of the stations that had a similarity of 0.434 , two groups of stations subject to the spatiotemporal dynamics of humid (group A) and humid subhumid (group B) bioclimates stood out, each of them being subdivided into two subgroups (A1, A2) and (B1, B2) (These elements are deduced from the knowledge of bioclimates and their floristic correspondences, [33] Joseph, 2012). These affinity groups between stations obtained with AHC analysis corroborated those obtained with the Correspondence Analysis (CFA) as represented in Figure 8. Second, the Ascending Hierarchical Classification carried out based on the populational structures of the species segregate three groups (I, II, III) which are completely separated and therefore have no similarity (similarity index equal to zero). Species in groups I and II have just about average to very low similarity in population structure between 0.075 and 0.46 (Figure 9). Group III, made up of two subgroups (IIIa and IIIb), includes the majority of the species whose degrees of populational similarity vary from 0.075 (IIIa: a single species) to 1 (Figure 9). Figure 9 shows a series of subdivisions, from the lowest value (0.0745) to the maximum value (1) of the index of similarity. This is to be compared with the number of species per inventory station. Subgroup IIIb is a suitable example of this. Its subdivisions, in particular IIIb2 and IIIb3, branch out into numerous units: IIIb2 [similarity index of 0.3 (all species in the subgroup) to 1] and IIIb3 [similarity index of 0.3 (all species in the subgroup) to 0.93]. Species with similarity indices between 0.85 and 1 have a high degree of similarity and form quantitatively variable corteges. The corteges of species whose similarity is between 0.925 and 1 are all separated. 


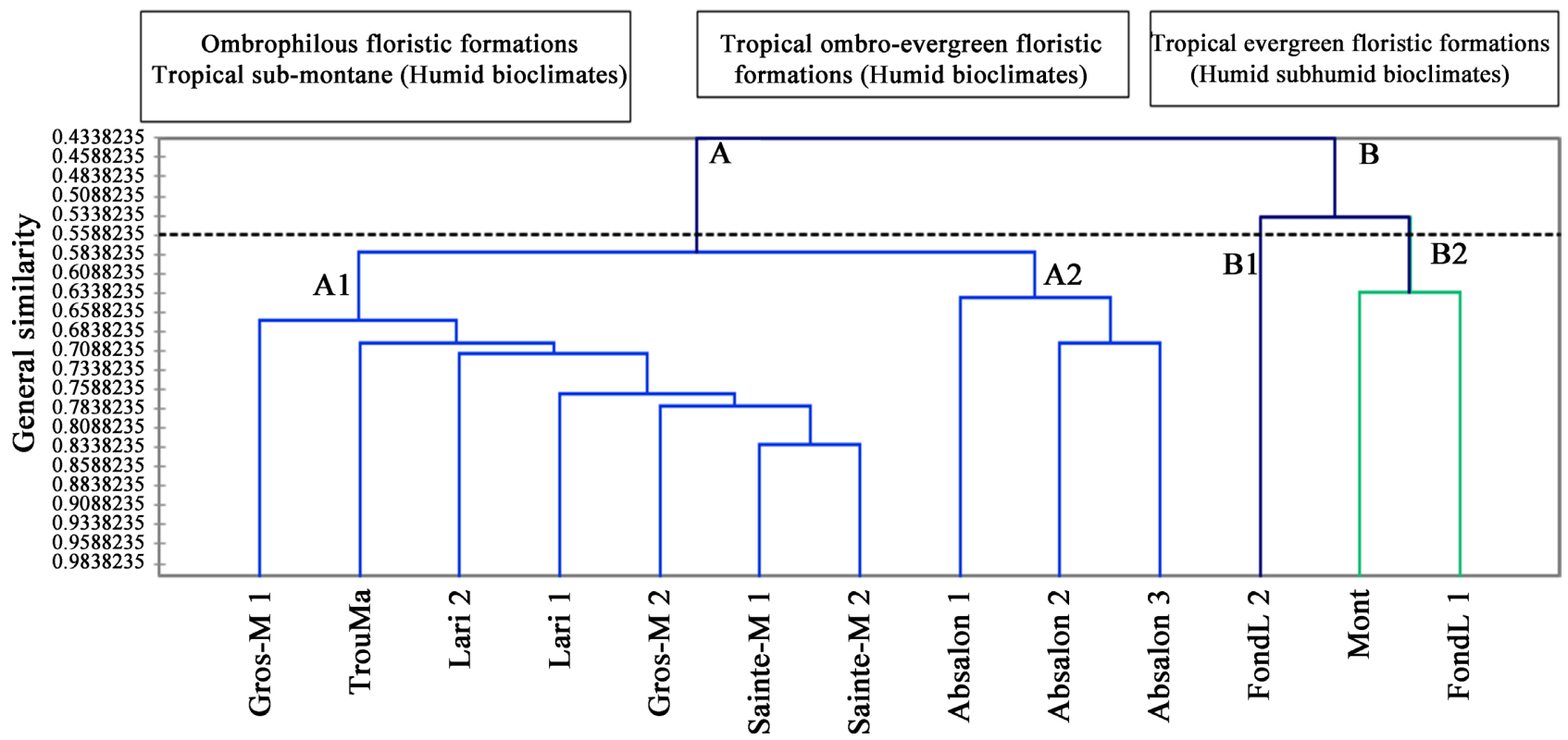

Figure 8. Biodemographic similarity of the stations.

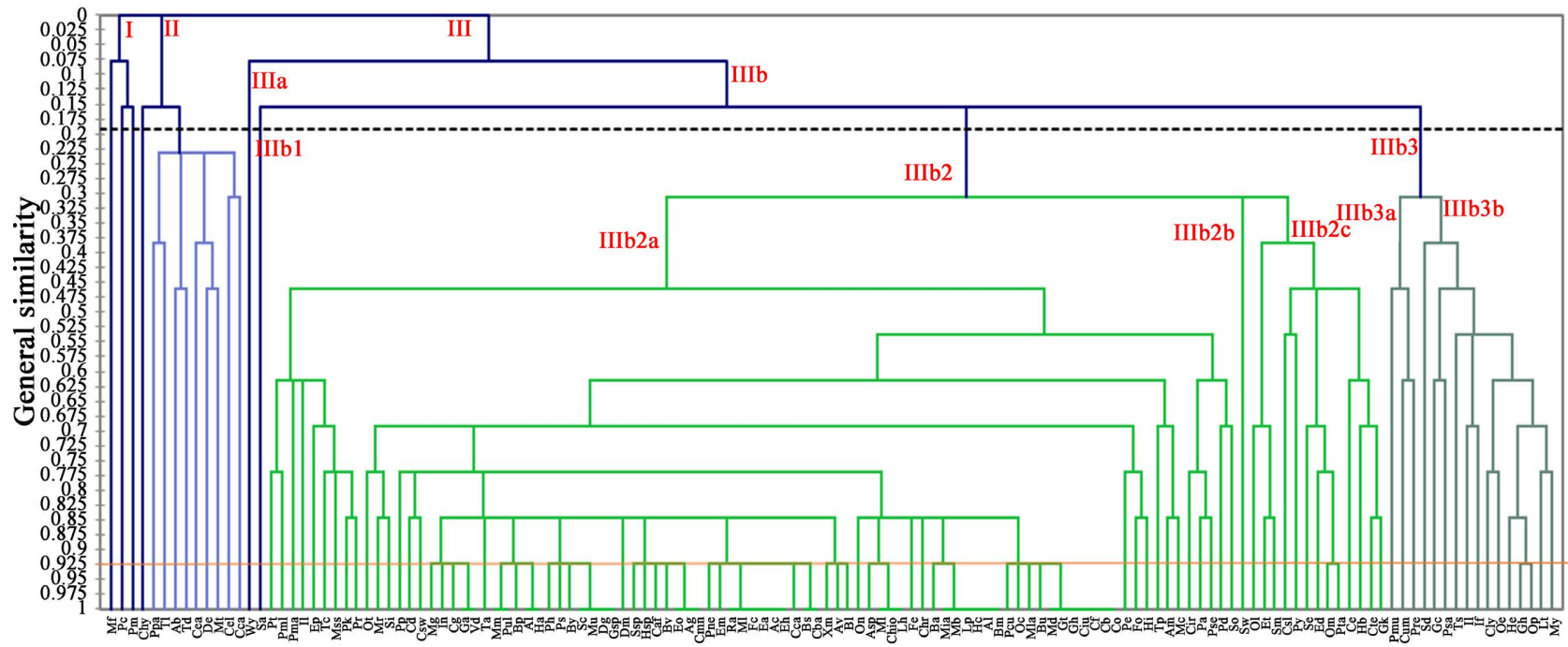

Figure 9. AHC (Ascending Hierarchical Classification) graph representing the ecosystemic similarity between species (see Box 1 of Figure 6(b) for abbreviations references).

\section{Discussion}

\subsection{Taxonomic Richness of the Naturally-Regenerating Flora under Mahoganys Plantation}

In view of the current knowledge of the forest flora of Martinique, the list of families to which the species inventoried under the mahogany plantations belong is not exhaustive over all the 13 stations influenced by humid and humid sub-humid bioclimates. Actually, the physical constraints imposed by mature populations of mahogany condition the colonization of the main singular and diverse floristic processions. So, if a larger number of stations had been considered in this study, other families could have been counted. The most frequent 
genera [FR $\geq 50 \%$ ] are typical of the sub-montane ombrophilous and seasonal ombro-evergreen floristic formations. The same applies for the species belonging to the bioclimates and types of vegetation mentioned above, except that the latter are associated with different stages of phytocenotic succession. Table 3 shows the most frequent naturally-regenerating species [FR $\geq 50 \%$ ]. There are few studies in the insular Caribbean and tropical America that could support our data with regard to taxonomic richness. However, the study by Udayana et al. (2020) in Indonesia on the evolution of autochthonous species richness in Teak and Mahogany plantations seems to show a correlation between the morphological development of these plantation forests and the increase in species diversity (Udayana et al., 2020). Wijesinghe and de Silva (2021) seem to show the same trends in their study "Conservation value of forest plantations: A study of four timber species in Sri Lanka” (Wijesinghe and de Silva, 2021). In his 1992 studies, A.E. Lugo demonstrates that mature plantations of Mahoganys and secondary forests under the same edaphic and climatic conditions presented an equivalent phytodiversity.

Table 3. Plant species presenting the most significant populations over all the thirteen stations.

\begin{tabular}{|c|c|c|c|}
\hline Species* & Plant Amilly & Plant habit & Preferential dynamic stages \\
\hline Aniba bracteata & Lauraceae & Tree & Late, pre-climax and climax forest stages \\
\hline Asplundia rigida & Cyclanthaceae & Herbaceous liana & Pre-climax and climax forest stages \\
\hline Cestrum laurifolium & Solanaceae & Bush to small tree & Secondary forest stages and large gaps in late and pre-climax forests \\
\hline Chimarrhis cymosa & Rubiaceae & Tree & Late, pre-climax and climax riparian forest stages \\
\hline Clidemia umbrosa & Melastomataceae & Bush & Bush and pre-forest stages, very large forest gaps \\
\hline Cordia sulcata & Boraginaceae & Tree & $\begin{array}{l}\text { Pre-forest, secondary forest stages and gaps in late and pre-climax } \\
\text { forests }\end{array}$ \\
\hline Cyathea arborea & Cyatheaceae & False tree & $\begin{array}{l}\text { Large gaps in secondary forests, pre-climax and climax, Areas in } \\
\text { perpetual rejuvenation }\end{array}$ \\
\hline Cyathea muricata & Cyatheaceae & False tree & Late, pre-climax and climax secondary forest stages \\
\hline Dacryodes excelsa & Burseraceae & Tree & Late, pre-climax and climax secondary forest stages \\
\hline Heliconia caribaea & Heliconiaceae & Large herbaceous & $\begin{array}{l}\text { Large gaps in secondary forests, pre-climax and climax, Areas in } \\
\text { perpetual rejuvenation }\end{array}$ \\
\hline Miconia trichotoma & Melastomataceae & Small tree & Large gaps in secondary forests, pre-climax and climax \\
\hline Myrcia fallax & Myrtaceae & Tree & Secondary forest stages and large gaps in late and pre-climax forests \\
\hline Palicourea crocea & Rubiaceae & Bush & Large gaps in secondary forests, pre-climax \\
\hline Piper dilatatum & Piperaceae & Bush & Large gaps in secondary forests, pre-climax \\
\hline Pouteria pallida & Sapotaceae & Tree & Late, pre-climax and climax forest stages \\
\hline Simarouba amara & Simaroubaceae & Tree & Small gaps in late-stage, pre-climax and climax forests \\
\hline $\begin{array}{l}\text { Talauma } \\
\text { dodecapetala }\end{array}$ & Magnoliaceae & Tree & Late, pre-climax and climax forest stages \\
\hline
\end{tabular}




\subsection{Lateral and Vertical Structure (Architecture) of Species Populations (All Stations)}

The classes of diameters and heights (total heights and first branchings) show a concentration of individuals in very low values, $2.5 \mathrm{~cm}-5 \mathrm{~cm}$ and $1 \mathrm{~m}-8 \mathrm{~m}$ respectively. This relates to the fact that the majority of individuals from the taxa that naturally regenerate under the plantations of Mahoganys of the inventory stations are in their expansion growth phase. Since there are three phases of growth development, i.e. initiation, expansion and maturity [17], these individuals are in the early stages of their morphological development. The diameter classes $2.5 \mathrm{~cm}$ and $5 \mathrm{~cm}$ as well as the height classes (total and first branchings) between $1 \mathrm{~m}$ and $8 \mathrm{~m}$ are the most represented. However, a small number of taxa differ due to their horizontal and vertical structures in which are represented few individuals in the classes of diameters greater than $25 \mathrm{~cm}$ as well as in classes of total heights and first branchings greater than $15 \mathrm{~m}$.

\subsection{Ecological Significance of the Species (All Stations)}

The index of distribution used in this study is a global index since the relative frequency (FR) and density (d) are global indicators relative to the set of stations. This index of distribution (Id) is highly variable and results from the common variability of the Relative Frequency (FR) of the species and the density (d) of their individuals. Indeed, the number of individuals varies both between the quadrats of the transects in the survey stations and between the transects. Generally speaking, naturally-regenerating species have a cumulative density of individuals (for the thirteen stations) which is low or very low, although this seems to be strongly correlated with the relative frequency. Within each inventory transect (station), the absolute frequency or number of species occurrences varies according to the quadrats as well as their populations. This heterogeneity is similar between stations. The most widely distributed species correspond to those with FR $\geq 69$ and d $\geq 0.005$ : Aniba bracteata, Cestrum laurifolium, Chimarrhis cymosa, Cyathea arborea, Cyathea muricata, Dacryodes excelsa, Miconia trichotoma, Myrcia fallax, Palicourea crocea, Piper dilatatum, Pouteria pallida, Talauma dodecapetala and Tapura latifolia. The preceding elements show that the naturally-regenerating species under the plantations of Mahoganys are little distributed (in other words, these native species are distributed randomly therefore heterogeneously. This is linked with their modes of clustering or "socialisation" ranging from dispersed to gregarious and the highly differentiated quantitative representativity of their populations. The reasons for this appear to originate from the strategies of dissemination of seeds or diaspores. For the dispersal of their seeds and in a proportional manner, it seems that the regenerating species favour zoochory (notably ornithochory) and barochory [34]. However, based on our experience in the field, we believe that in the case of trees, which belong to the most represented plant habit, barochory conditions higher densities of gregarious populations when the following two categories of autochthon- 
ous seed trees are present: relict trees with low growth found within or at the edge of Mahoganys plantations which belonged to ancient natural forest groupings, and adult trees with average or fast growth which have developed within the Mahoganys plantations [33].

As shown by the results of both the Correspondence Factorial Analyses (CFA) and the Ascending Hierarchical Classifications (AHC), the topographic and pedoclimatic factors and the dissemination vectors as well as the phenology of the seed trees adjoining the stations are determining factors which condition the structure of populations of regenerating. These are affiliated to humid, humid subhumid and dry subhumid bioclimates and consist of sub-montane ombrophilous, seasonal ombro-evergreen and seasonal evergreen phytocenoses respectively. When the individuals of the different taxa are few and distributed in a large number of stations, one may think that ornithochore dissemination is the most effective [35]. However, when there are a large number of individuals and they are distributed in a low number of stations, the predominance of barochory seems to be the most plausible explanation (Personal observations). On the other hand, there may be situations where the species have low relative frequencies with sparse populations. In the latter case, it is very likely that these species are largely barochoric and have phenological peculiarities resulting in infructescences with small fruits (Personal observations). The phase difference between the external environment (macroclimate) and the internal environment of these "Mahogany plantation" systems characterized by a very simplified stratification would be in relation with multiple sites of installation and expansion of fairly specific factorial characteristics. Indeed, in these artificial forests, the very simplified stratification is composed of a dominant upper stratum of adult Mahoganys, a middle stratum composed of scattered juvenile Mahoganys and mature autochthonous trees. This type of forest structure, associated with the deficiency of the disseminator vector fauna, could explain the low population densities of the vast majority of the species. In general, this study shows that mature plantations of a not very competitive introduced forest species such as Sweetenia spp. facilitates phytocenotic succession and the development of a quite highly diverse indigenous flora [36]-[41].

\section{Conclusion}

Despite their non-contiguous crowns forming a sparse canopy, the plantations of Mahoganys impose geometric constraints allowing the colonization of species of natural flora. The floristic differences observed between the inventory stations largely depend on the seed dispersal processes and the ecological factors. Among these are the stational bioclimates, the topography and the edaphic conditions. There are also other parameters such as the quantitative significance of the seed trees adjoining the planted plots and the frequency of flooding and exposure of low-lying riparian terraces. Naturally-regenerating species present a broad taxonomic spectrum and belong to stages of the plant dynamic ranging from pio- 
neer to climax stages through post-pioneer stages. The fact that the species of advanced stages (pre-climax and climax stages) regenerate under mature plantations of Mahoganys constitutes a shortcut to the dynamics of the vegetation. Indeed, species such as Aniba bracteata, Guatteria caribaea, Chimarrhis cymosa, Dacryodes excelsa, Pouteria multiflora, Pouteria pallida, Sloanea dendata, Sloanea dussii, Sloanea massoni, Talauma dodecapetala and Tapura latifolia are predominantly matrix species of mature pre-climax and climax forest groupings of humid and humid subhumid bioclimates. Pimenta racemosa is a dominant taxon [high distribution (Id) and high overall basal area] of the advanced phases of the phytocenotic succession of pre-climax and climax forest formations influenced by the dry subhumid bioclimate. The other taxa listed are characteristic of various types of sylvatic gaps and severely degraded forests which are known as regressive (young and secondary forests). Considering our previous findings [17] [42], this study shows that the Mahoganys plantations can be used as an ecological engineering tool to activate plant dynamics, particularly in highly diminished or unstructured environments with humid, humid subhumid and dry subhumid bioclimates. Anthropisation, as well as the frequent cyclonic hazards, leads to a regression from the forest stage to the herbaceous, bush or mixed stage of the advanced, pre-climax and climax plant ecosystems. In this respect, the requirements of forestry, in particular to facilitate the cutting and extraction of logs, should not be reached considering the too large spacing between commercially-exploitable specimens in such too old Mahoganys plantations [43]. With the aim of ecological restoration, the dense plantation of Mahoganys would be the most appropriate solution because at the end of the growth of individuals, shorter exclusion distances between them lead to an internal environment that is much more dephased in relation to the macroclimate

\section{Acknowledgements}

Our thanks go first to the members of the Antilles "BIORECA" group from the "UMR ESPACE DEV" laboratory and secondly to the CTM (Local Authority of Martinique) and the University of the Antilles which annually fund our research programmes.

\section{Conflicts of Interest}

The authors declare no conflicts of interest.

\section{References}

[1] Hawkes, J.G., Maxted, N. and Ford-Lloyd, B.V. (2000) Evolution of Plants under Domestication. In: The Ex Situ Conservation of Plant Genetic Resources, Springer, Dordrecht, 19-31. https://doi.org/10.1007/978-94-011-4136-9 2

[2] Simons, A.J. and Leakey, R.R.B. (2004) Tree Domestication in Tropical Agroforestry. In: Nair, P.K.R., Rao, M.R. and Buck, L.E., Eds., New Vistas in Agroforestry, Springer, Dordrecht, 167-181. https://doi.org/10.1007/978-94-017-2424-1 12

[3] Smith, B.D. (1997) The Initial Domestication of Cucurbita pepo in the Americas 
10,000 Years Ago. Science, 276, 932-934.

https://doi.org/10.1126/science.276.5314.932

[4] Borrell, F., Junno, A. and Barceló, J.A. (2015) Synchronous Environmental and Cultural Change in the Emergence of Agricultural Economies 10,000 Years Ago in the Levant. PLoS ONE, 10, e0134810. https://doi.org/10.1371/journal.pone.0134810

[5] Montoya, E., Lombardo, U., Levis, C., Aymard, G.A. and Mayle, F.E. (2020) Human Contribution to Amazonian Plant Diversity: Legacy of Pre-Columbian Land Use in Modern Plant Communities. In: Rull, V. and Carnaval, A., Eds., Neotropical Diversification: Patterns and Processes, Springer, Cham, 495-520. https://doi.org/10.1007/978-3-030-31167-4 19

[6] Pagán Jiménez, J.R. (2011) Early Phytocultural Processes in the Pre-Colonial Antilles. In: Hofman, C.L. and van Duijvenbode, A., Eds., Communities in Contact. Essays in Archaeology, Ethnohistory, and Ethnography of the Amerindian CircumCaribbean, Sidestone Press, Leiden, 87-116.

[7] Parker, I.M., López, I., Petersen, J.J., Anaya, N., Cubilla-Rios, L. and Potter, D. (2010) Domestication Syndrome in Caimito (Chrysophyllum cainito L.): Fruit and Seed Characteristics. Economic Botany, 64, 161-175.

https://doi.org/10.1007/s12231-010-9121-4

[8] Olschewski, R. and Benítez, P.C. (2010) Optimizing Joint Production of Timber and Carbon Sequestration of Afforestation Projects. Journal of Forest Economics, 16, $1-10$.

[9] Ivantsova, E., Krylov, P., Novochadov, V., Onistratenko, N. and Matveeva, A. (2019) Components of Anthropogenically Transformed Landscapes of South of Russia Interaction. Proceedings of the IV International Scientific and Practical Conference: Anthropogenic Transformation of Geospace: Nature, Economy, Society (ATG 2019), Volgograd, 1-4 October 2019, 80-83. https://doi.org/10.2991/aer.k.200202.017

[10] Silantyeva, M.M., Elesova, N.V., Hensen, I., Terekhina, T.A., Grebennikova, A.Y. and Ovcharova, N.V. (2020) Influence of Agricultural Reclamation on Vegetation Cover and Biodiversity in the Forests and Steppes of Kulunda. In: Frühauf, M., Guggenberger, G., Meinel, T., Theesfeld, I. and Lentz, S., Eds., KULUNDA: Climate Smart Agriculture, Springer, Cham, 143-154. https://doi.org/10.1007/978-3-030-15927-6 10

[11] Castilla-Beltrán, A., de Nascimento, L., Fernández-Palacios, J.M., Fonville, T., Whittaker, R.J., Edwards, M. and Nogué, S. (2019) Late Holocene Environmental Change and the Anthropization of the Highlands of Santo Antão Island, Cabo Verde. $\mathrm{Pa}$ laeogeography, Palaeoclimatology, Palaeoecology, 524, 101-117.

https://doi.org/10.1016/j.palaeo.2019.03.033

[12] Tubiello, F.N., Salvatore, M., Ferrara, A.F., House, J., Federici, S., Rossi, S., et al. (2015) The Contribution of Agriculture, Forestry and Other Land Use Activities to Global Warming, 1990-2012. Global Change Biology, 21, 2655-2660. https://doi.org/10.1111/gcb.12865

[13] Wingfield, M.J., Coutinho,TA, Roux, J. and Wingfield, B.D. (2002) The Future of Exotic Plantation Forestry in the Tropics and Southern Hemisphere: Lessons from Pitch Canker. Southern African Forestry Journal, 195, 79-82.

https://doi.org/10.1080/20702620.2002.10434607

[14] Nishijima, S., Furukawa, T., Kadoya, T., Ishihama, F., Kastner, T., Matsuda, H. and Kaneko, N. (2016) Evaluating the Impacts of Wood Production and Trade on Bird Extinction Risks. Ecological Indicators, 71, 368-376.

https://doi.org/10.1016/j.ecolind.2016.07.008 
[15] Francis, J.K. and Lowe, C.A. (2000) Silvics of Native and Exotic Trees of Puerto Rico and the Caribbean Islands (Spanish Version). General Technical Report IITF-GTR15 US Department of Agriculture, Forest Service International Institute of Tropical Forestry. https://doi.org/10.2737/IITF-GTR-15

[16] Norghauer, J.M., Martin, A.R., Mycroft, E.E., James, A. and Thomas, S.C. (2011) Island Invasion by a Threatened Tree Species: Evidence for Natural Enemy Release of Mahogany (Swietenia macrophylla) on Dominica, Lesser Antilles. PLoS ONE, 6, e18790. https://doi.org/10.1371/journal.pone.0018790

[17] Joseph, P. (2009) La végétation forestière des Petites Antilles: Synthèse biogéographique et écologique, bilan et perspectives. KARTHALA, Paris.

[18] Joseph, P. (2012) The Vegetation of the Lesser Antilles: Floristic Diversity and Ecosystemic Dynamics. International Journal of Environmental Studies, 69, 816-833,

[19] Garmon, W.T. Allen, C.D. and Groom, K.M. (2017) Geologic and Tectonic Background of the Lesser Antilles. In: Allen, C., Ed., Landscapes and Landforms of the Lesser Antilles, Springer, Cham, 7-15. https://doi.org/10.1007/978-3-319-55787-8 2

[20] Costa, C.H., Audin, L. and Benavente, C. (2009) Geomorphology as a Tool for Analysis of Seismogenic Sources in Latin America and the Caribbean. Developments in Earth Surface Processes, 13, 29-47. https://doi.org/10.1016/S0928-2025(08)10002-5

[21] DeWalt, S.J., Ickes, K. and James, A. (2016) Forest and Community Structure of Tropical Sub-Montane Rain Forests on the Island of Dominica, Lesser Antilles. Caribbean Naturalist, No. 1, 116-137.

[22] Howard, R.A. (1962) Volcanisme et végétation dans les Petites Antilles. Journal de I Arnold Arboretum, 43, 279-314. https://doi.org/10.5962/p.185646

[23] Krisnawati, H., Kallio, M.H. and Kanninen, M. (2011) Swietenia macrophylla King: Ecology, Silviculture and Productivity. CIFOR.

[24] Snook, L.K. (1996) Catastrophic Disturbance, Logging and the Ecology of Mahogany (Swietenia macrophylla King): Grounds for Listing a Major Tropical Timber Species in CITES. Botanical Journal of the Linnean Society, 122, 35-46. https://doi.org/10.1111/j.1095-8339.1996.tb02061.x

[25] Stehlé, H. (1957) Les Mahoganys des Antilles françaises et le Swietenia Aubrevilleana Stehlé et Cusin, nov. spec. (25 Contribution). Bulletin de la Société Botanique de France, 104, 41-51. https://doi.org/10.1080/00378941.1957.10835161

[26] Krishna, S. and Maurya, H. (2018) A Review on Favorable Approaches of Swietenia macrophylla Plant for the Human Ailments. Indian Journal of Pharmaceutical and Biological Research, 6, 60-65. https://doi.org/10.30750/ijpbr.6.3.10

[27] Castañeda-Posadas, C. and Cevallos-Ferriz, S.R. (2007) Swietenia (Meliaceae) Flower in Late Oligocene-Early Miocene Amber from Simojovel de Allende, Chiapas, Mexico. American Journal of Botany, 94, 1821-1827.

[28] Brown, N., Jennings, S. and Clements, T. (2003). The Ecology, Silviculture and Biogeography of Mahogany (Swietenia macrophylla): A Critical Review of the Evidence. Perspectives in Plant Ecology, Evolution and Systematics, 6, 37-49. https://doi.org/10.1078/1433-8319-00041

[29] Gleason, H.A. and Panshin, A.J. (1936) Swietenia Krukovii: A New Species of Mahogany from Brazil. American Journal of Botany, 23, 21-26.

[30] Mabberley, D.J. (1982) William Roxburgh's 'Botanical Description of a New Species of Swietenia (Mahogany)' and Other Overlooked Binomials in 36 Vascular Plant Families. Taxon, 31, 65-73.

[31] Joseph, P. (2015) Attempt to Understand the Relationship between the Water of the 
Soil System and the Vegetation: The Case of the Martinique Lower Vegetation Floor. Journal of Advances in Biology, 6, 1161-1188.

[32] Joseph, P., Baillard, K., Claude, J.P., Abati, Y., Major, P., Duranty, J., Sophie, S. and Ely-Marius, S. (2018) The Floristic Heritage Groups of the French Antilles: Operative Elements in the Planning of Natural Environments (The Example of Martinique). Journal of Geography and Geology, 10, 17-42.

[33] Joseph, P. (2015) The Final Stages of Vegetal Dynamics in the Lesser Antilles (A Few Theories). International Journal of Science and Research (IJSR), 4, 1151-1164.

https://www.ijsr.net/get abstract.php?paper id=NOV151356 https://doi.org/10.21275/v4i11.NOV151356

[34] Joseph, P., Claude, J.P., Baillard, K., Abati, Y., Jean-Francois, Y., Major, P., et al. (2020) Contribution to the Knowledge of the Phytocenotic Diversity of the Lesser Antilles Revisiting Some Old and More Recent Floristic Data. Open Access Library Journal, 7, 1-44.

[35] De Foresta, H., et al. (1984) Zoochorie et premiers stades de la régénération naturelle après coupe en forêt guyanaise. Revue d' Écologie, 39, 369-400.

[36] Bremer, L.L. and Farley, K.A. (2010). Does Plantation Forestry Restore Biodiversity or Create Green Deserts? A Synthesis of the Effects of Land-Use Transitions on Plant Species Richness. Biodiversity and Conservation, 19, 3893-3915. https://doi.org/10.1007/s10531-010-9936-4

[37] Boakye, E.A., et al. (2012) Does Forest Restoration Using Taungya Foster Tree Species Diversity? The Case of Afram Headwaters Forest Reserve in Ghana. African Journal of Ecology, 50, 319-325.

[38] Paquette, A. and Messier, C. (2010) The Role of Plantations in Managing the World's Forests in the Anthropocene. Frontiers in Ecology and the Environment, 8, 27-34.

[39] Verheyen, K., Vanhellemont, M., Auge, H., Baeten, L., Baraloto, C., Barsoum, N., et al. (2016) Contributions of a Global Network of Tree Diversity Experiments to Sustainable Forest Plantations. Ambio, 45, 29-41. https://doi.org/10.1007/s13280-015-0685-1

[40] Aide, T.M., Clark, M.L., Grau, H.R., López-Carr, D., Levy, M.A., Redo, D., et al. (2013) Deforestation and Reforestation of Latin America and the Caribbean (20012010). Biotropica, 45, 262-271.

[41] Lugo, A.E. (1992) Comparison of Tropical Tree Plantations with Secondary Forests of Similar Age: Ecological Archives M062-001. Ecological Monographs, 62, 1-41.

[42] Udayana, C., Andreassen, H.P. and Christina Skarpe, C. (2020) Understory Diversity and Composition after Planting of Teak and Mahogany in Yogyakarta, Indonesia. Journal of Sustainable Forestry, 39, 494-510. https://doi.org/10.1080/10549811.2019.1686029

[43] Sarmiento, R. and Varela, R. (2015) Assessing the Biomass Potential of Major Industrial Tree Plantation Species for Green Energy Production. Open Journal of Forestry, 5, 557-562. https://doi.org/10.4236/ojf.2015.55049 